\title{
THE CLEVEREST MAN IN THE WORLD
}

\section{Problemsolved.}

\section{BY TONY BALLANTYNE}

" $\mathrm{H}$ $\mathrm{i}$, this is Clark Maxwell, the cleverest man in the world. Ten seconds, $€ 10,000$. Off you go!"

“Clark! My name's Bob. My parachute's broken! What should I do?"

"Hi Bob. Let me see. GPS has you at 20,000 feet over Arizona. That's pretty high up! Given a terminal velocity of 180 feet per second, you've just under two minutes before you hit the ground."

"I know! What do I do?"

"That's a tough one! Give me a minute to think..."

"What? No! Don't hang..."

Too late. Clark checked the volume of space around Bob on his computer and switched to the next call in the queue.

"Hi, this is Clark Maxwell, the cleverest man in the world. Ten seconds, $€ 10,000$. Hit me!"

"This is James Sunderland, chief executive of eToys. Clark, we've got a spy in the company. Every new product we develop, our competitors get to market weeks before we do."

"Spies aren't your only problem then, you must be very inefficient in terms of product manufacture."

"Oh. What should we do?"

"That's two questions, James. Just give me a second ..."

Clark called up eToys on a second monitor. Keeping one eye on Bob's rapid descent, he ran a number of searches in quick succession.

"James! You'd have had the answer yourself if you'd taken the trouble to check your network audit trails. The plans are being deliberately downloaded onto games cartridges as part of the background scenery. Your competitors are buying your secrets wholesale. Now for your second question, may I suggest that you make an appointment with my PA to discuss looking at your company from top to bottom."

"Uh, sure. Thanks, Clark."

"Don't mention it. Bob! How's it going?"

"Still falling, Clark."

"I see that. Bob, I want you to look down. Do you see the big lake?"

"Yes. Should I aim for it?"

"No! But don't you find it beautiful? Calming even?"

"No. Should I?"

"Back soon, Bob ... $\mathrm{Hi}$, this is Clark Maxwell, the cleverest man

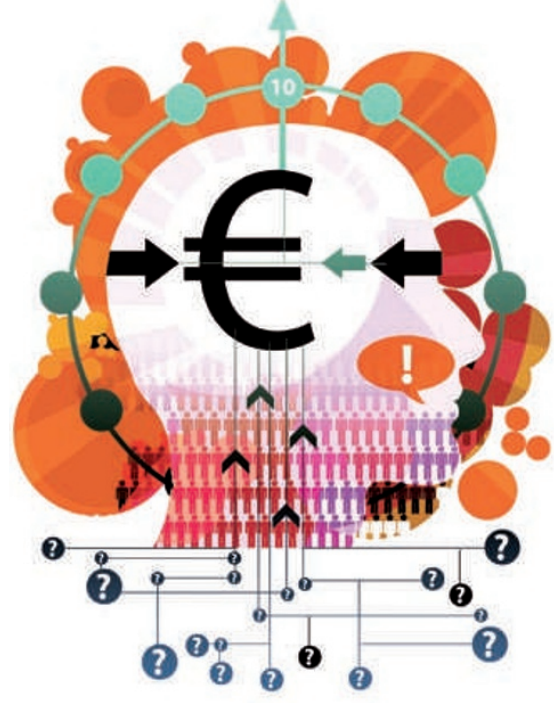

in the world. Ten seconds, $€ 10,000$. What's the problem?"

"This is Lewis. Can't seem to get a girlfriend, Clark."

"Hmm. That's because you're so selfobsessed. Get a hair cut and start paying attention to someone beside yourself."

"Hey, can you see me?"

"No. Never seen you in my life, Lewis."

"Then how do you know that's true? About the haircut and everything?"

"You've got $€ 10,000$ to spare and you're using it to ask a stranger how to get a girl. Anyone who thinks that money solves all their problems is probably pretty selfobsessed. Time's up!"

"But..."

Clark tapped at his keyboard.

"Hi Bob! I can see you now."

"How?"

"I've taken control of the plane you jumped from."

"Can you do that?"

"Did I mention I was the cleverest man in the world? Hold it, Bob, I'll be back in a minute!"

"I don't have a minute!"

"Hi, this is Clark Maxwell, the cleverest man in the world. Ten seconds, $€ 10,000$. How can I be of service?"

"Clark, this is your wife, the smartest woman in the world. Have you walked off with my car keys again?"

"Sorry, Lois. Will you be home tonight?"

"Assuming I get the supercollider fixed. I think I know what's causing the problem. It's not its future self it's interfering with, it's its past self."
"Sounds cool, dear. Got to go! Hi, this is Clark Maxwell, the cleverest man in the world. Ten seconds, $€ 10,000$. Hit it!"

"Clark, this is Tessa Walkiewicz, Acronym News. We're doing a report on the acceleration of change and we'd like a few words ..."

"Certainly, Tessa. Just a moment... Bob, you're falling too fast. Hold your arms and legs wide. I'm sure you've seen people do it in films!"

"It looks easier in films, Clark."

"I know! Just do your best! Marianne is jumping out of the plane, right now. She's got a spare chute for you."

"What plane?"

"Your plane, Bob. The one you jumped out of. It's right behind you!"

"Oh! That's clever!"

"That's my job ... back in a moment, Bob. Tessa! What's the question?"

"Well, Clark. Given the growth of the Internet and the new paradigms of interconnectivity, people such as yourself are emerging as a powerful force for social change. Plugged into the world's data streams, you have a view of everything changing from minute to minute."

"That's not a question, Tessa."

"No, that's an intro, Clark. The question is this: given that people are using services such as yours more and more, does that mean they are getting less intelligent?"

"I hardly think that many people are using my service, Tessa. Not at the prices I charge!"

"Maybe not yours, Clark, but given that the answer to any problem you have is only a phone call away, why should people think for themselves anymore?"

"Let me turn that around, Tessa. When they stop thinking, they stop being people. Got to go!"

"But..."

"Hi, this is Clark Maxwell, the cleverest man in the world. Ten seconds, $€ 10,000$. I'm listening!"

"Uh, Clark, this is Marianne. I jumped out of the plane, I've attached myself to Bob."

"Well done Marianne! What's the problem?"

"It's my 'chute. It's failed to open, too. The ground's looking awfully close."

"Marianne, thank you! I do like a challenge! Now, listen to me carefully ..."

Tony Ballantyne has had short stories published in magazines and anthologies around the world. His latest novel, Blood And Iron, is published by Tor UK. 